\title{
Study the effect of partially replacement sand by waste pistachio shells in cement mortar
}

\author{
Zainab Hashim Abbas Alsalami*
}

*Correspondence:

zainab89@wrec.uoqasim. edu.iq

Department of Sustainable Management, College

of Water Resources Engineering, Al-Qasim Green University, Al-Qasim District, Babylon, Iraq 51013

\begin{abstract}
The most economic and environmental problems result from burial agricultural waste materials. The main objective of the present investigation is to assess the usefulness of agricultural waste in mortar admixture. These materials are expected to reduce the density of the admixture, and thus producing lightweight mortar.This study aims to study the effect of using pistachio shells as partial replacement of sand on the properties of cement mortar. Furthermore, the effect of density, absorption, and compressive strength of cement mortar were also obtained.Ordinary Portland cement from Kufa Cement Plant was used with a water cement ratio of 0.48 and a mix proportion of 1:3, also six percentages of pistachio shells were used $(10,20,30,40,50$ and $60 \%$ by weight of fine aggregate).A total number of 84 mortar cubes were casted with 12 cubes for each mixture ratio. From 84 mortar cubes 21 cubes were utilized to calculate the average water absorption and 63 cubes were utilized to calculate the average density and compressive strength.Compressive strength values of the mortar cubes were evaluated at 7, 14, 28 days at different percentage replacement levels obtaining a range of values of $6.78,8.92$ and $14.1 \mathrm{MPa}$, respectively at $20 \%$ replacement.The density values were reduced with the increment in replacement levels until it reached $(1.21$ and 1$) \mathrm{gm} / \mathrm{cm}^{3}$ at 28 days with replacement percentages of (50 and 60\%) respectively.Water absorption was increased with the increment in replacement levels and reaching (6.04\%) at (60\%) replacement level.
\end{abstract}

Keywords: Pistachio shells, Compressive strength, Density and absorption

\section{Introduction}

The high cost of construction materials is a major problem in the construction industry. Therefore, researchers tend to study more economic materials such as agricultural and industrial waste Materials. However, these waste materials if not charged safely it may be dangerous. The manufacture of traditional masonry materials consume a lot of thermal and electrical power and in return it turn contaminates the air, water and land.

Other benefits of using agricultural waste materials in the construction industry instead of naturalistic materials are protection of natural resources, elimination of waste materials and release of precious ground for different purposes.

Pistacia vera is an individual from the Anacardiaceae or cashew family. Pistachio trees are separate sex, implying that there are isolated male and female trees. The criterion male class is "Peters", the essential vaccinator for "Kerman", the principle female class [1].

(c) The Author(s) 2017. This article is distributed under the terms of the Creative Commons Attribution 4.0 International License (http://creativecommons.org/licenses/by/4.0/), which permits unrestricted use, distribution, and reproduction in any medium, provided you give appropriate credit to the original author(s) and the source, provide a link to the Creative Commons license, and indicate if changes were made. 
The pistachio is local to the Asia Minor region, from the islands of the Mediterranean in the west to India in the east. Furthermore, it is broadly found in Syria, Iraq and Iran. It presumably created in inside wilderness zones, since it demands extended, warm summers for organic product development, is dry season and salt tolerant, in addition to that has a high winter severe prerequisite. Figure 1 explains Pistacia vera fruits.

Several researchers have discussed the replacement of sand by many types of waste materials; Ganiron studied the use of recycled glass bottles as fine aggregates in concrete mixture. He concluded that the use of recycled glass bottles as an alternative fine aggregate for concrete mix decreases the unit weight of concrete, the value of modulus of elasticity and cost of concrete, he also concluded that the use of recycled bottles as an alternative of fine aggregate is not recommended for structural members such as columns, beams and suspended slabs [2].

Sada et al. investigated the use of groundnut as a replacement of fine Aggregate; they found that the use of groundnut shell in concrete reduces the concretes workability due to the high absorption of water by the groundnut shell; the densities and compressive strength of concrete decreased with the increase in groundnut shell percentage [3].

Obilade conducted experimental study on rice husk as fine aggregates in concrete; he found that the density reduces with the increase in the percentage of husk rice, he also concluded that there is a high potential for the use of rice husk as fine aggregate in the production of lightly reinforced concrete [4].

Mortar is a mixture of sand, cement and water. The main difference between mortar and concrete is mortar does not have coarse aggregate.

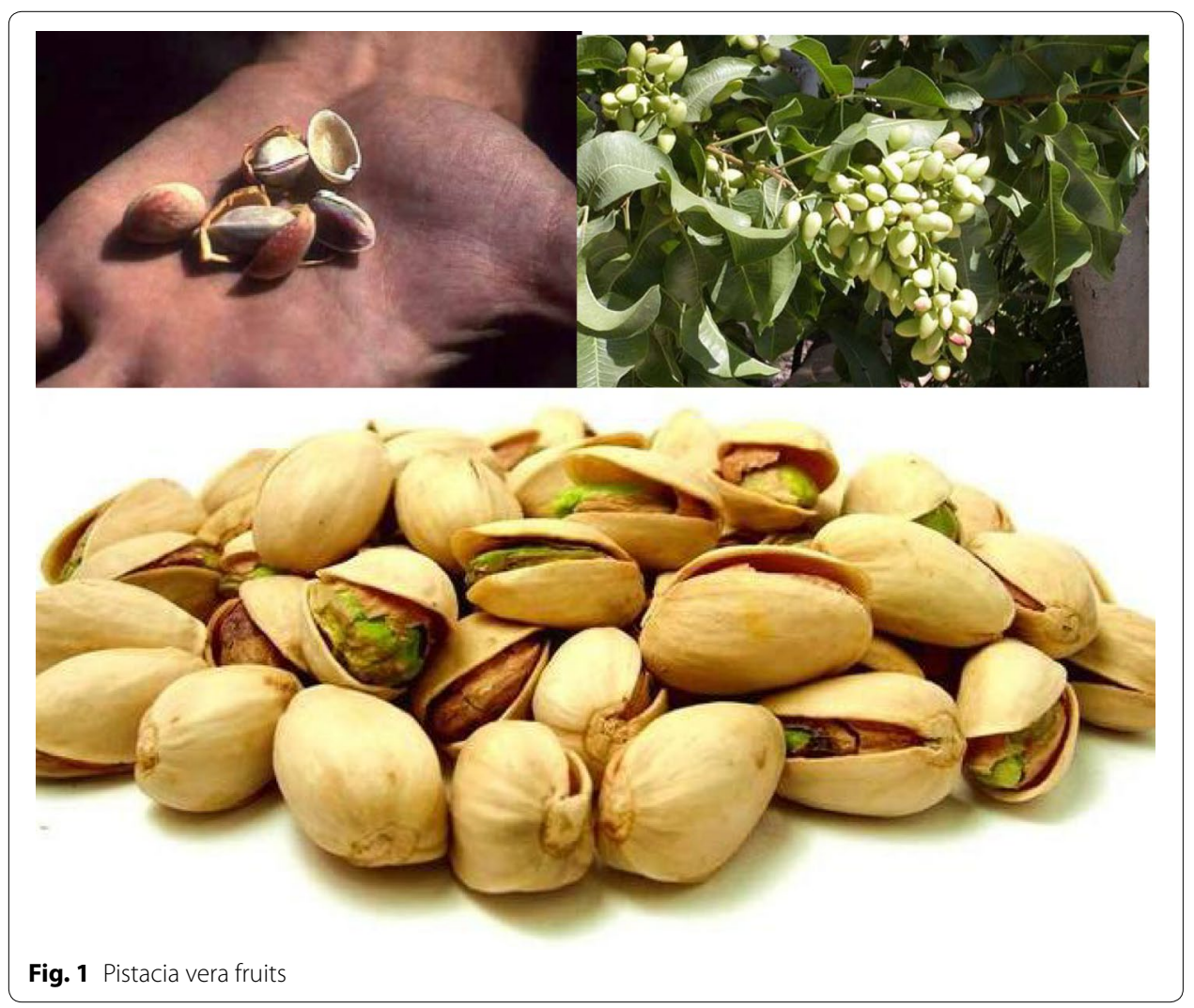


Mohammed stated that as a result of the heterogeneity of the mortar, its technique of conduct under various load impacts is subject to the properties of the constituents of the mortar. Sand has an important effect on the characteristics of the mortar because it forms the master volume of mortar; therefore the chosen of convenient aggregates in mortar is very substantial [5].

De Schutter and Poppe demonstrate an exceptionally noteworthy impact of the sand sort on the mortar properties [6].

Mortar is the material responsible for the dividing of stresses in building structures; therefore studying the properties of mortar is significant to ensure a good performance of masonry structures [7].

Lenczner stated that the main purpose of mortar is to adhesively join the individual masonry units together. It also provides defense against the permeation of air and water through the joints in a masonry assembly. Mortar also links the non-masonry elements of an assembly such as joint reinforcement and ties. Minor dimensional variations in the masonry units have also been compensated by mortar. Finally, mortar joints have important effect on architectural quality of construction through colour and shadow [8].

Mortars are characterized into four Types: M, S, N and O by ASTM C 270, 2006 [9]:

- Type N mortar: General universally aims mortar with great binding abilities and workability.

- Type S mortar: General universally aims mortar with higher flexural bond quality.

- Type M mortar: High compressive-quality mortar, however not exceptionally workable.

- Type O mortar: Low-strength mortar, utilized generally for inside applications and reclamation.

\section{Materials and methods}

\section{Cement}

Ordinary Portland Cement (OPC) according to ASTM C150 Type 1 [10] commercially accessible in Kufa cement plant.

Test results indicated that the embraced cement adjusts to Iraqi specifications IQS No. $5 / 1984[11]$

The chemical composition and physical properties of this OPC were given in Tables 1, 2 respectively.

\section{Sand}

The fine aggregate utilized throughout this work are brought from AL-Ekhadir region. Tests have been completed to decide the gradation, fineness modulus, and sulfate content. Results demonstrated that the fine aggregate were conformed to the requirements of IQS No. 45/1984 [12] as shown in Tables 3, 4.

\section{Pistachio shells}

The pistachio shells were acquired from Hila city as a waste from shops which sell pistachio. The shells shown in Fig. 2 were washed, sun dried for 7 days (Sun drying was important to simplicity expulsion of the meat from the inward shells of the pistachio 
Table 1 Chemical composition of cement

\begin{tabular}{|c|c|c|c|}
\hline Compound composition & Chemical composition & Percentage by weight & Limits of IQS 5:1984 \\
\hline Lime & $\mathrm{CaO}$ & 60.77 & - \\
\hline Silica & $\mathrm{SiO}_{2}$ & 19.35 & - \\
\hline Alumina & $\mathrm{Al}_{2} \mathrm{O}_{3}$ & 5.2 & - \\
\hline Iron oxide & $\mathrm{Fe}_{2} \mathrm{O}_{3}$ & 3.6 & - \\
\hline Magnesia & $\mathrm{MgO}$ & 2.95 & $<5$ \\
\hline Sulfate & $\mathrm{SO}_{3}$ & 2.5 & $<2.8$ \\
\hline Loss on ignition & L.O.I & 1.15 & $<4$ \\
\hline Insoluble residue & I.R & 0.2 & $<1.5$ \\
\hline Lime saturation factor & L.S.F & 0.5 & $0.66-1.02$ \\
\hline \multicolumn{4}{|c|}{ Main compounds (Bogue's equation) percentage by weight of cement } \\
\hline \multicolumn{3}{|l|}{ Tricalcium silicate $\left(\mathrm{C}_{3} \mathrm{~S}\right)$} & 53.0569 \\
\hline \multicolumn{3}{|l|}{ Dicalcium silicate $\left(\mathrm{C}_{2} \mathrm{~S}\right)$} & 15.5296 \\
\hline \multicolumn{3}{|l|}{ Tricalcium aluminate $\left(C_{3} A\right)$} & 7.696 \\
\hline \multicolumn{3}{|c|}{ Tetraclcium aluminoferrite $\left(\mathrm{C}_{4} \mathrm{AF}\right)$} & 10.944 \\
\hline
\end{tabular}

Table 2 Physical properties of cement

\begin{tabular}{lll}
\hline Physical properties & Test results & Limits of (IQS NO. 5/1984) \\
\hline Setting time (Vicat's Method) & & \\
Initial, (min) & 124 & $\geq 45 \mathrm{~min}$ \\
Final, (min) & 420 & $\leq 600 \mathrm{~min}$ \\
Fineness (Blaine Method), $\mathrm{m}^{2} / \mathrm{kg}$ & 307 & $\geq 230 \mathrm{~m}^{2} / \mathrm{kg}$ \\
\hline
\end{tabular}

Table 3 Grading of fine aggregate

\begin{tabular}{llll}
\hline No. & Sieve size $(\mathbf{m m})$ & Passing \% & Limits of Iraqi specification no. 45/1984 for zone $\mathbf{2}$ \\
\hline 1 & 9.5 & 100 & 100 \\
1 & 4.75 & 98.2 & $90-100$ \\
2 & 2.38 & 80.7 & $75-100$ \\
3 & 1.18 & 69.8 & $55-90$ \\
4 & 0.59 & 50.6 & $35-59$ \\
5 & 0.30 & 27.7 & $8-30$ \\
6 & 0.15 & 4.2 & $0-10$ \\
\hline
\end{tabular}

Table 4 Physical and chemical properties of fine aggregate

\begin{tabular}{llll}
\hline No. & Properties & Test results & Limits of Iraqi specification no. 45/1984 \\
\hline 2 & $\mathrm{SO}_{3}$ content & $0.42 \%$ & $\leq 0.5 \%$ \\
3 & Fineness modulus & 2.688 & - \\
\hline
\end{tabular}

pieces), afterward the Pistachio shells were squashed utilizing electric power grinder machine shown in Fig. 3 to diminish it to sizes similar to fine aggregate as determined in IQS No. 45/1984 [12]. 



The pistachio shells were sieved by utilizing $4.75 \mathrm{~mm}$ sieve to dispense with harmful materials and curiously large particles.

Some physical tests performed on pistachio shells sample are displayed in Table 5.

For determining the specific gravity of pistachio shells, flask, measuring balance, filtered water and a drying material were utilized as a part of the assurance of specific gravity of pistachio shells. Vacuous, pure and arid specific gravity flask with its plug was measured $\left(\mathrm{W}_{1}\right)$. The flask was filled to $33 \%$ full with the pistachio shells specimen and 
Table 5 Physical properties of pistachio shells

\begin{tabular}{ll}
\hline Physical properties & Test results \\
\hline Fine modulus & 2.582 \\
Specific gravity & 0.12 \\
\hline
\end{tabular}

rebalanced $\left(\mathrm{W}_{2}\right)$. A little quantity of filtered water was then included and the jug substance vibrated to evacuate trapped air. Vibration proceeded and more water included until the point that the container was full. The plug was embedded and abundance water cleaned on flask and measured $\left(\mathrm{W}_{3}\right)$. The container from that point was discharged, altogether cleaned and swabbed dry and after that loaded with filtered water and the plug embedded and overabundance water swabbed and measured $\left(\mathrm{W}_{4}\right)$.

Calculation of specific gravity for pistachio shells were as follows:

$$
S . G=\frac{\mathrm{W}_{2}-\mathrm{W}_{1}}{\left(\mathrm{~W}_{4}-\mathrm{W}_{1}\right)-\left(\mathrm{W}_{3}-\mathrm{W}_{2}\right)}
$$

where: $\mathrm{W}_{1}=$ weight of empty flask, $(85 \mathrm{gm}), \mathrm{W}_{2}=$ weight of flask + cement, $(109 \mathrm{gm})$, $\mathrm{W}_{3}=$ weight of flask + cement + water, $(206 \mathrm{gm}), \mathrm{W}_{4}=$ weight of flask + water, $(383$ gm).

\section{Experimental set up}

Mixing by weight approach was embraced in this examination work. A blend proportion of 1:3 (by weight of cement: fines) with a water cement proportion of 0.48 were kept constant for all the blends. The substitution ratios of fine aggregate with pistachio shells were $0,10,20,30,40,50$ and $60 \%$ by weight of the fine aggregate to study the impacts of various extents of the pistachio shells on a few properties of mortar. Table 6 displays the computed masses of constituent materials for all blends. The $0 \%$ substitution filled in as control for different blends. Compressive strength as per B.S 1881-part 4-1989 [13], by utilizing $200 \mathrm{KN}$ limit testing machine was done on mortar samples that were molded utilizing steel molds of sizes $(70.6,70.6,70.6 \mathrm{~mm})$. The molds were amassed and greased up preceding molding for simple evacuation of cubes; machine vibration was utilized through the molding. The mortar solid shapes were de-formed $24 \mathrm{~h}$ subsequent to molding and were cured for 7, 14, 28 days.

Table 6 Mix proportions for one cube

\begin{tabular}{lllllcl}
\hline Mix no. & Mix ID & Water/cement ratio & Cement $(\mathbf{g})$ & Sand $(\mathbf{g})$ & Pistachio shells $(\mathbf{g})$ & Water (m) \\
\hline 1 & $F_{100} \mathrm{P}_{0}$ & 0.48 & 200 & 600 & 0 & 96 \\
2 & $\mathrm{FA}_{90} \mathrm{P}_{10}$ & 0.48 & 200 & 540 & 60 & 96 \\
3 & $\mathrm{FA}_{80} \mathrm{P}_{20}$ & 0.48 & 200 & 480 & 120 & 96 \\
4 & $\mathrm{FA}_{70} \mathrm{P}_{30}$ & 0.48 & 200 & 420 & 180 & 96 \\
5 & $\mathrm{FA}_{60} \mathrm{P}_{40}$ & 0.48 & 200 & 360 & 240 & 96 \\
6 & $\mathrm{FA}_{50} \mathrm{P}_{50}$ & 0.48 & 200 & 300 & 300 & 96 \\
7 & $\mathrm{FA}_{40} \mathrm{P}_{60}$ & 0.48 & 200 & 240 & 360 & 96 \\
\hline
\end{tabular}


A similar process to ASTM C642-06 standard test method [14] for density, absorption, and voids in hardened concrete was used to measure density and absorption.

Density test was done on mortar shape before testing of compressive strength such mortar solid shape was weighted and separated weight on volume of mold rate of three molds was computed for each blend and each age.

\section{Absorption test}

After 28 days curing the specimens were taken out from curing tank. Specimens are dried in an oven at $105^{\circ} \mathrm{C}$ for $24 \mathrm{~h}$. The dry specimens were cooled to room temperature $\left(25^{\circ} \mathrm{C}\right)$ weighed accurately and noted as dry weight. Then dry specimens were immersed in a water container. Weight of the specimen at predetermined intervals was taken after wiping the surface with dry cloth. This process is to be continued not less than $48 \mathrm{~h}$ or up to constant weight are to be obtained in two successive observations.

The dry weight of mortar solids were measured and noted as weight $\left(\mathrm{w}_{1}\right)$. Then the dry mortar solid were totally inundated in water at room temperature for $24 \mathrm{~h}$. Following $24 \mathrm{~h}$ the mortar solids were expelled from the water, permitted to deplete and any hints of water were wiped out with moist material as appeared in Fig. 4. At that point this weight was noted as the wet weight $\left(\mathrm{w}_{2}\right)$. From the raise in weight of the samples, water absorption amounts were obtained as percentage of dry weight.

Calculation of water absorption was as follows:

$$
\text { Water absorption } \%=\frac{\mathrm{w}_{2}-\mathrm{w}_{1}}{\mathrm{w}_{1}}
$$

where: $\mathrm{w}_{1}=$ dry weight of mortar solid, $(\mathrm{gm}), \mathrm{w}_{2}=$ weight of solid mortar after $24 \mathrm{~h}$ immersion in water, (gm).

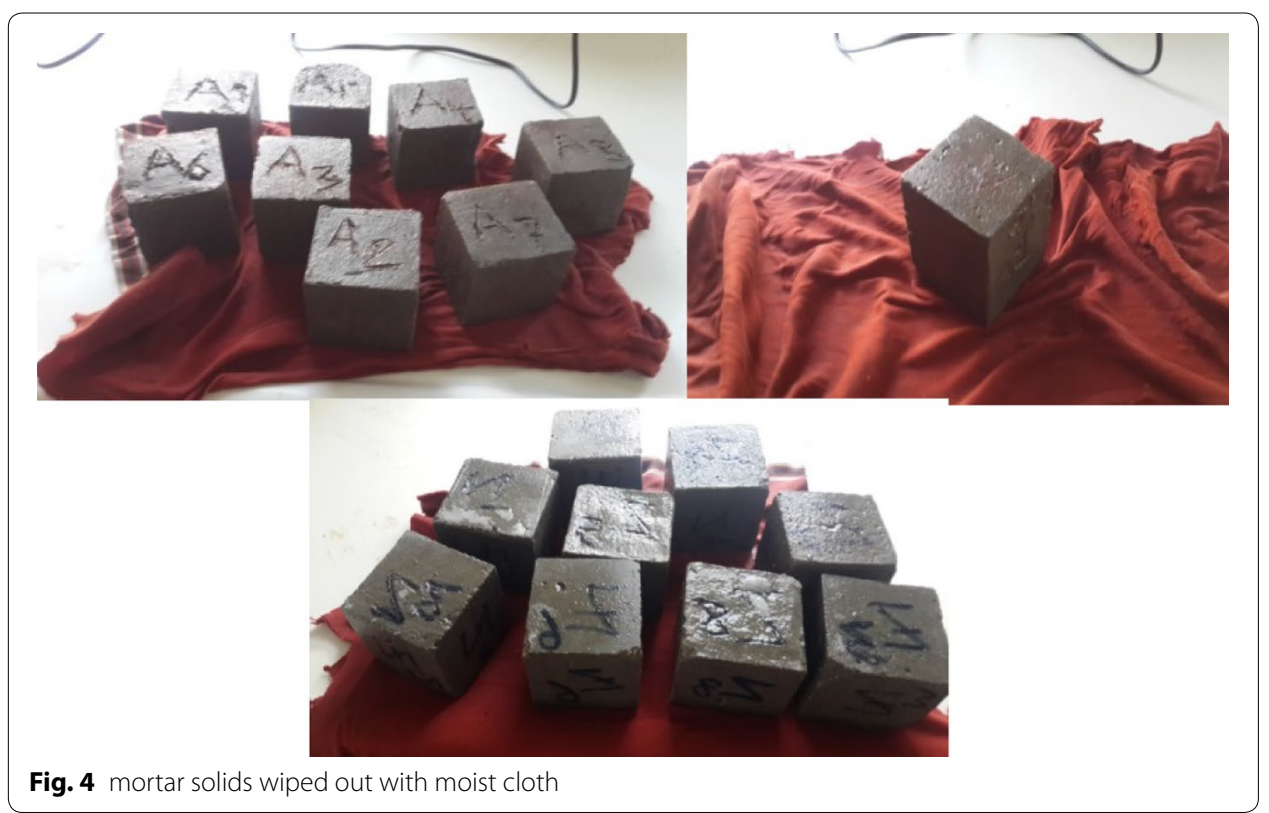


Fully 84 mortar cubes were molded with 12 cubes for each mixture ratio. From 84 mortar cubes 21 cubes were utilized to calculate the average water absorption and 63 cubes were utilized to calculate the average density and compressive strength.

Each specimen was weighed to detect the density before subjecting the specimens to compression test.

\section{Result and discussion}

The results of compressive strength, density and absorption are shown in Table 7.

Figures 5 and 6 show change of compressive strength with age and with variable of replacement ratios, respectively. Figure 7 shows variable of density with age at different replacement ratios. Figure 8 explains absorption at different replacement ratios.

Table 7 Compressive strength, density and absorption

\begin{tabular}{|c|c|c|c|c|c|c|c|}
\hline \multirow[t]{2}{*}{ Mixes } & \multicolumn{3}{|c|}{ Compressive strength (MPa) } & \multicolumn{3}{|c|}{ Density $\left(\mathrm{gm} / \mathrm{cm}^{3}\right)$} & \multirow[t]{2}{*}{ Absorption (\%) } \\
\hline & 7 days & 14 days & 28 days & 7 days & 14 days & 28 days & \\
\hline $\mathrm{FA}_{100} \mathrm{P}_{0}$ & 31.52 & 42.14 & 71.47 & 2.243362 & 2.263926 & 2.315841 & 0.469529 \\
\hline $\mathrm{FA}_{90} \mathrm{P}_{10}$ & 27.85 & 31.46 & 51.54 & 2.179786 & 2.185617 & 2.207969 & 0.804359 \\
\hline $\mathrm{FA}_{80} \mathrm{P}_{20}$ & 6.78 & 8.92 & 14.1 & 1.9302 & 1.940099 & 1.962099 & 2.036351 \\
\hline $\mathrm{FA}_{70} \mathrm{P}_{30}$ & 3.06 & 4.02 & 6.2 & 1.68 & 1.69 & 1.71 & 3.2 \\
\hline $\mathrm{FA}_{60} \mathrm{P}_{40}$ & 2.11 & 3.01 & 4.35 & 1.43 & 1.44 & 1.46 & 4.01 \\
\hline $\mathrm{FA}_{50} \mathrm{P}_{50}$ & 1.8 & 1.92 & 2.5 & 1.18 & 1.19 & 1.21 & 5.03 \\
\hline $\mathrm{FA}_{40} \mathrm{P}_{60}$ & 1.02 & 1.25 & 1.75 & 0.97 & 0.98 & 1 & 6.04 \\
\hline
\end{tabular}

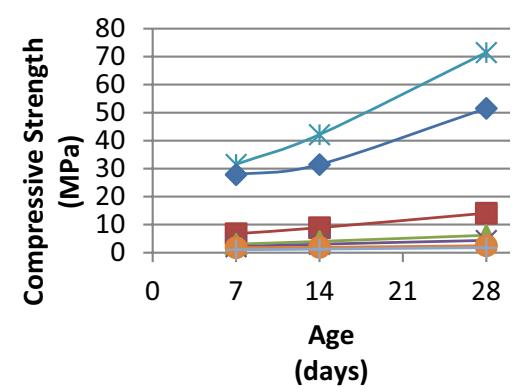

* $0 \%$ replacement

$-10 \%$ replacement

$-20 \%$ replacement

$-30 \%$ replacement

$\leftarrow 40 \%$ replacement

$-50 \%$ replacement

$+60 \%$ replacement

Fig. 5 Compressive strength-age (with different replacement ratios)

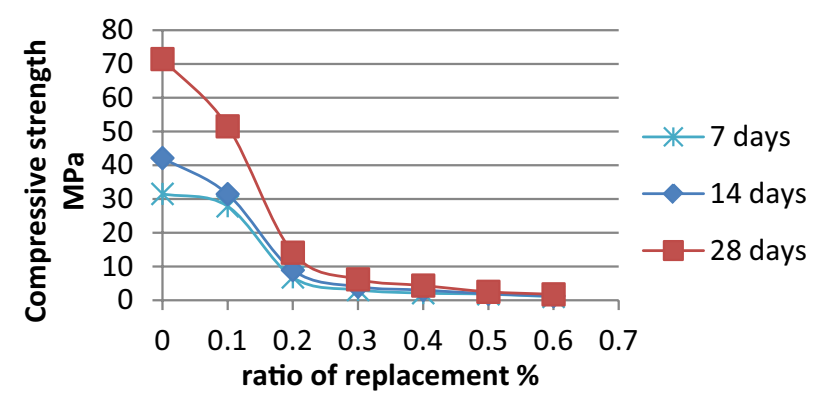

Fig. 6 Compressive strength-ratio of replacement (at different curing time) 

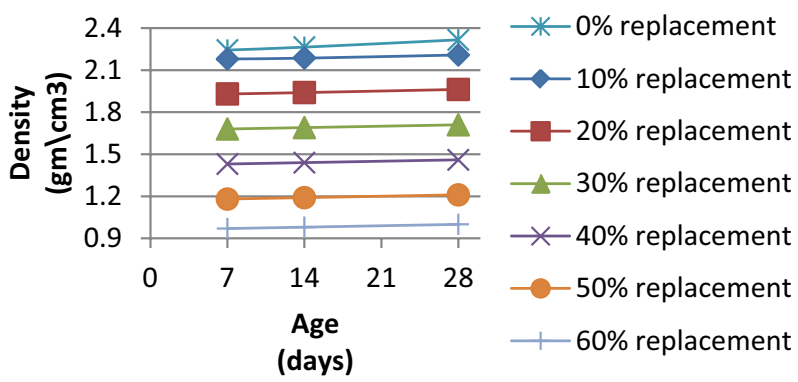

Fig. 7 Density—age (with different replacement ratios)



Fig. 8 Absorption (with different replacement ratios)

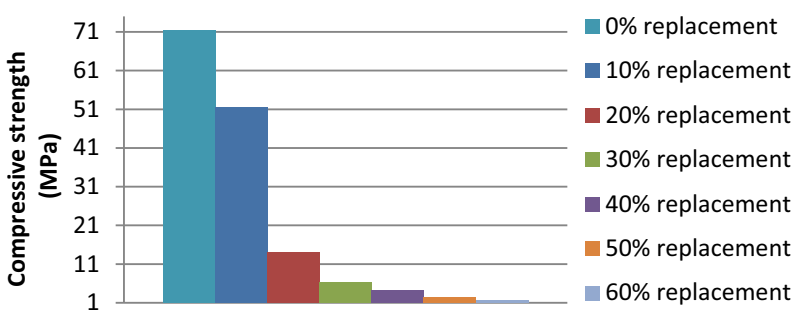

Fig. 9 Compressive strength at 28 days (with different replacement ratios)

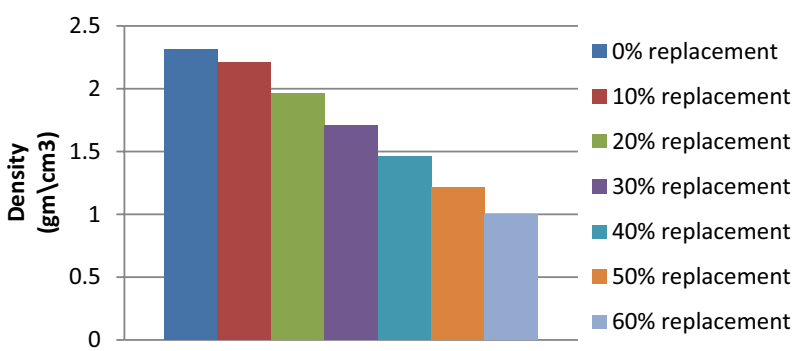

Fig. 10 Density at 28 days (with different replacement ratios)

Figures 9 and 10 explain compressive strength and density at 28 days with different replacement ratios, respectively. Figures 11 and 12 explain variable compressive strength and absorption with density at 28 days with different replacement ratios, respectively. 



Fig. 11 Compressive strength — density at 28 days (with different replacement ratios)


Fig. 12 Compressive strength—absorption at 28 days (with different replacement ratios)

From Figs. 5, 6 were concluded that compressive strength increases with age and decreases with increasing ratio of replacement in agreement with Sada et al. who investigated the use of groundnut as a replacement of fine aggregate [3].

Neville, 2011 stated that the increasing in compressive strength with age that was because of continuation of hydration of anhydrate cement with time which composes a new output of hydration within the mortar mass [15].

The reduction in compressive strength with the increase in replacement levels might be attributed to the low workability of the mixture resulted from the absorption of water by the pistachio shells during mixing. Furthermore, the low density of pistachio shells as compared with that of fine aggregate may also contribute in the reduction of the compressive strength as shown in Fig. 10 and Table 7, which show that the density decreases with the increment in replacement ratio. This also coincides with the observations of Obilade who studied the influence of replacing fine aggregates by husk rice on the concrete properties [4]. Also, it was clear that mortar with $30 \%$ replacement and above could be used for non-load bearing purposes, and mortar with $20 \%$ replacement and below could be used for loading bearing purposes according to the requirements of ASTM C270, 2014 [9].

It also clear that mixes at 50 and $60 \%$ replacement level achieve lightweight mortar density requirement according to BS EN 998-2, 2010 [16].

From Figs. 7, 10 illustrate that density increase with age that was because of hydration of cement and close the pores and make the mortar denser [15], but density decrease with increase of replacement because of pistachio shells have less density than that of used sand. 
From Fig. 11 shows that compressive the strength decrease with the decrement in density at 28 days with different replacement levels. The reduction might be attributed to increasing pores with decreasing density.

From Fig. 12 illustrates that the compressive strength decreases with increasing absorption at 28 days with different replacement levels, this might be due to absorption of water of hydration.

\section{Conclusions}

1. Compressive strength decreases with the increment in replacement level of pistachio shells and increases with age.

2. Density decreases with the increment in replacement level of pistachio shells due to low density of pistachio shells as compared with that of used fine aggregate.

3. Density increases with age that was because of hydration of cement and closes the pores and makes the mortar denser.

4. Absorption increases with the increment in replacement level of pistachio shells might be due to porous texture of pistachio shells.

5. Compressive strength decrease with increasing absorption.

6. Compressive strength decreases with decrement in density.

7. Mortar with $30 \%$ replacement and above could be used for non-loading bearing purposes.

8. Mortar with $20 \%$ replacement and below could be used for loading bearing purposes.

9. Mortar at 50\% and 60\% replacement level achieve lightweight mortar.

\section{Abbreviations}

$\mathrm{W}_{1}$ : weight of empty flask; $\mathrm{W}_{2}$ : weight of flask + cement; $\mathrm{W}_{3}$ : weight of flask + cement + water; $\mathrm{W}_{4}$ : weight of flask + water; S.G: specific gravity; $\mathrm{w}_{1}$ : dry weight of mortar solid, (gm); $\mathrm{w}_{2}$ : weight of solid mortar after $24 \mathrm{~h}$ immersion in water, (gm)

\section{Acknowledgements}

I wish to thanks College of Water Resources Engineering \Al-Qasim Green University for providing an opportunity to do research work in the laboratory.

Competing interests

The author declares that she has no competing interests.

Availability of data and materials

Not applicable.

Consent for publication

The author consents to the publication process.

Ethics approval and consent to participate

The author consents to the ethics.

Funding

No funding Information available (no fund organization but I will pay the fees for publishing).

\section{Publisher's Note}

Springer Nature remains neutral with regard to jurisdictional claims in published maps and institutional affiliations.

Received: 13 October 2017 Accepted: 29 November 2017

Published online: 05 December 2017 


\section{References}

1. Nwangwu AC. Genetic variability in a representative'Kerman'x'Peters' population of pistachio (Pistacia vera L.) orchard. M.sc. Thesis of Biotechnology in the College of Science and Mathematics California State University, Fresno May 2015.

2. Ganiron TU Jr. Use of recycled glass bottles as fine aggregates in concrete mixture. Int J Adv Sci Technol. 2013;61:17-28.

3. Sada BH, Amartey YD, Bakoc S. An Investigation Into the Use of Groundnut as Fine Aggregate Replacement. Niger J Technol. 2013;32(1):54-60.

4. Obilade IO. Experimental study on rice husk as fine aggregates in concrete. Int J Eng Sci. 2014;3(8):9-14.

5. Mohammed A, Hughes TG, Abubakar A. Importance of sand grading on the compressive strength and stiffness of lime mortar in small scale model studies. Open J Civil Eng. 2015:5:372-8. https://doi.org/10.4236/ojce.2015.54037.

6. De Schutter G, Poppe AM. Quantification of the water demand of sand in mortar. Construct Build Mater. 2004;18(7):517-21

7. Vladimir GH, Graça V, Paulo BL. Influence of aggregates grading and water/cement ratio in workability and hardened properties of mortars. Constr Build Mater. 2011;25:2980-7.

8. Lenczner D. Elements of loadbearing brickwork. Oxford: Pergamon Press; 1972

9. ASTM C. 270 standard specification for mortar for unit masonry, annual book of standards. 04th ed. West Conshohocken: ASTM International; 2006

10. ASTM C. 150 standard specification for Portland cement. West Conshohocken: American Society for Testing and Materials; 2005.

11. Iraqi Specification. No.5, Portland cement. Baghdad; 1984.

12. Iraqi Specification. No.45, Aggregate from natural sources for concrete and construction. Baghdad; 1984.

13. BS. 1881- Part 4, Method for determination of compressive strength of cement mortar. British Standard 1989.

14. ASTM C. 642 Standard test method for density, absorption, and voids in hardened concrete. West Conshohocken: ASTM International; 2006. https://doi.org/10.1520/C0642-06.

15. Neville AM. Properties of concrete. New York and Longman: Wiley; 2011. p. 844.

16. BS EN. 998-2 Specification for mortar for masonry-part 2: Masonry mortar, British Standards Document. 2010.

\section{Submit your manuscript to a SpringerOpen ${ }^{\circ}$ journal and benefit from:}

- Convenient online submission

Rigorous peer review

Open access: articles freely available online

- High visibility within the field

Retaining the copyright to your article

Submit your next manuscript at $\boldsymbol{\Delta}$ springeropen.com 